Науковий вісник Дьвівського націонадьного університету ветеринарної медицини та біотехнологій імені С.З. Гжицького

\author{
Scientific Messenger of Lviv National University \\ of Veterinary Medicine and Biotechnologies
}

UDC 631.232.2:658.5.

\title{
Resource-saving milk production technologies with use of easy-assembled premises and high-performance milking plants
}

\author{
M.M. Lutsenko, O.Yu. Galay
}

Bila Tserkva National Agrarian University, Bila Tserkva, Ukraine

Article info

Received 17.02.2018

Received in revised form 12.03 .2018

Accepted 15.03.2018

Bila Tserkva National Agrarian University, sq. Cathedral, 8/1, Bila Tserkva, Kyiv region, 09100, Ukraine. Tel.: +38-045-639-18-36 E-mail: tehnologkaf@ukr.net, GalOks09@mail.ru
Lutsenko, M.M., \& Galay, O.Yu. (2018). Resource-saving milk production technologies with use of easy-assembled premises and high-performance milking plants. Scientific Messenger of Lviv National University of Veterinary Medicine and Biotechnologies. 20(84), 166-170. doi: $10.15421 /$ nvlvet8430

High productivity of dairy cows in the conditions of new innovative technologies can not be obtained without providing comfortable conditions for their functioning.In this connection, the conditions for maintaining high-yielding cows in various types of livestock buildings are investigated: the traditional, 24.0 $m$ wide and new unassembled, $32.5 \mathrm{~m}$ wide and $36.0 \mathrm{~m}$ in extreme periods of the year. The different width of the premises is due to the need to use different types of milking plants: MilkProud, Parallel, Carousel and robotic milking systems. Studies have established that volumetric-planning and technological solutions for easy-assembled premises increase the volume of space per head from $45.6 \mathrm{~m}^{3}$ to $96.3 \mathrm{~m}^{3}$ and $129.6 \mathrm{~m}^{3}$. It positively affects the conditions for the maintenance of highly productive cows. The presence in their design of side curtains and light-aeration ridge increases the speed of air in 3 times. This provides a reduction in the concentration of ammonia in 8 times, and bacterial pollution at 18.7 times compared with traditional barn.Increasing the volume of the room up to $129.6 \mathrm{~m}^{3}$ per head reduces the bacterial air pollution in the winter period to a minimum value of 2.8 thousand $/ \mathrm{m}^{3}$. New elements in the design of easy-assembled spaces provide resource-saving and organizing their lighting.According to the existing standards in Ukraine, the lighting in the feeding area should be at 52 lux. In traditional rooms, this level is achieved only by installing additional energy sources, which provide an increase in lighting from 31 lux to 52 lux. In new types of premises the required level of lighting is provided naturally, which leads to significant energy savings. It was established that technological solutions of easy-assembled premises provide comfortable conditions for recreation of high-yielding cows.In these types of rooms, the animals rest $12.4 \%$ and $20.0 \%$ more time compared to traditional rooms. Feeding of cows in easy-assembled premises from the stern table provides quick feeding of animals with feed. At the same time the time consumed for feed consumption in new types of barns is significantly less and is 252.0-246.0 min a day compared to $320.2 \mathrm{~min}$ in traditional premises where feeding is carried out from traditional feeding troughs.It is positive that in the new types of premises in animals there is a new important element of behavior - the movement, which they spend $8.6 \%$ and $9.9 \%$ of the time. New types of premises with resource-saving milk production technologies have a positive effect on the conditions for the maintenance of highly productive cows and can be widely implemented in Ukraine.

Key words: resource-saving technologies, easy-assembled premises, maintenance conditions, efficiency, productivity of animals.

\section{Ресурсозберігаючі технології виробництва молока з використанням легкозбірних приміщень та високопродуктивних доїльних установок}

\author{
М.М. Луценко, О.Ю. Галай
}

Білоцерківський національний аграрний університет, м. Біла Церква, Украӥна

Високої продуктивності молочних корів в умовах нових інноваційних технологій неможливо отримати без забезпечення комфортних умов їх функціонування. В зв'язку з цим досліджено умови утримання високопродуктивних корів в різних типах тваринницьких приміщень: традиційному, иириною 24 м і нових легкозбірних, иириною 32,5 м та 36 м в екстремальні періоди року. Різна иирина приміщень обумовлена необхідністю використання різних типів доӥльних установок: «Молокопровід», «Паралель», «Кару- 
сель» та роботизованих систем дойняя. Проведеними дослідженнями встановлено, щзо об'ємно-планувальні і технологічні рішення

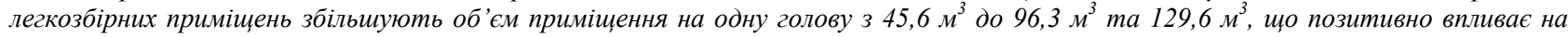
умови утримання високопродуктивних корів. Наявність в їх конструкції бокових штор та світлоаераційного гребеня збільшують швидкість руху повітря у 3 рази, щио забезпечує зниження концентрації аміаку у 8 разів, а бактеріальне забруднення повітря у 18,7 разів у порівнянні з традиційним корівником. За рахунок бокових штор і світлоаерачійного гребеня у нових типах корівників забезпечується нормативна освітленість, шчо виключає необхідність додаткового освітлення, а відповідно, $і$ забезпечує економію енергоресурсів. Встановлено, щзо технологічні рішення легкозбірних приміщень забезпечують комфортні умови відпочинку високопродуктивних корів. В зв'язку з чим в цих типах приміщень тварини відпочивають на 12,4\% та 20\% більше часу у порівнянні з традиційними приміщеннями. Позитивним є $і$ те, щуо в нових типах приміщень у тварин появляється новий, надзвичайно важливий, елемент поведінки - пересування, на який вони витрачають 8,6\% та 9,9\% часу доби. Нові типи приміщень з ресурсоощадними технологіями виробництва молока позитивно впливають на умови утримання високопродуктивних корів $і$ можуть иироко впроваджуватись вУкраӥні.

Ключові слова: ресурсоощадні технологї, легкозбірні приміщення, умови утримання, ефективність, продуктивність тварин.

\section{Вступ}

Перспективний розвиток молочного тваринництва України неможливий без впровадження нових ресурсоощадних технологій виробництва молока, які б за умовами утримання високопродуктивних корів та економічними показниками відповідали європейському рівню (Lopez et al., 2004; Lutsenko et al., 2006; Guetouache et al., 2014). Це обумовлено тим, що в даний час на існуючих молочних фермах країни в основному використовуються застарілі технології, які покладені в основу приміщень, побудованих за проектами 40-50 річної давності. При розробці цих проектів основним критерієм ставилась вартість одного скотомісця і зовсім не враховувались фізіологічні потреби тварин, особливо високопродуктивних. В зв'язку 3 цим усі вони були зорієнтовані на прив'язне утримання корів, де основним принципом $є$ те, що тварину обслуговує людина.

При прив'язній технології утримання тварин практично неможливе використовувати високопродуктивну доїльну техніку, тому навантаження на одного оператора не перевищувало більше 50 корів (Mazurenko, 2011; Norman et al., 2012). При цій технології спостерігаються великі затрати праці на обслуговування самої тварини, зокрема, на забезпечення процесу годівлі, напування, прибирання гною та інші операції. В зв'язку з цим затрати праці на виробництво 1 ц молока в Україні сягають 15 людино-годин в той час як в європейських країнах вони знаходяться на рівні 1-2 людино-годин (Bozhydarnyk and Krysanov, 2011; Bilchenko, 2011).

При таких затратах праці виробництво молока в багатьох господарствах $є$ збитковим. Тому, сьогодні настала нагальна необхідність впровадження нових ресурсоощадних технологій, які б за рівнем виробництва відповідали європейським вимогам (Lutsenko and Sameha, 2007; Grainger et al., 2008; Ghassemi Nejad et al., 2017).

Розробка і впровадження сучасних технологій є надзвичайно актуальним так, як Урядом України плануються серйозні інвестиції у відродження галузі молочного тваринництва.

Технології виробництва молока, які сьогодні використовуються на фермах України, в основному зорієнтовані на прив'язне утримання корів 3 доїнням їх на самих недосконалих доїльних установках типу «Молокопровід» та доїння у відро. Такі типи доїльних установок використовуються в європейських країнах лише в родильних відділеннях чи ізоляторах ферми. А основними установками, які забезпечують доїння високопродуктивних корів $є$ доїльні установкиплощадки. Тому, використовуючи досвід європейських країн молочні ферми України необхідно переводити на доїння корів в доїльних залах, що є базовим елементом ресурсозбереження при виробництві молока (Rushen et al., 1999; LeBlanc, 2013; Ghassemi Nejad et al., 2017).

Другим, не менш важливим елементом в технології виробництва молока, є забезпечення комфортних умов утримання тварин, особливо високопродуктивних. Існуючі типи приміщень, що використовуються на фермах України побудовані за проектами 50-60 річної давності і вони не забезпечують нормальних умов функціонування високопродуктивних корів. Тому, сьогодні, надзвичайно актуальним є питання будівництва нових типів приміщень, які б були зорієнтовані на ресурсоощадні технології виробництва молока забезпечували комфортні умови утримання тварин та доїння їх в спеціалізованих доїльних залах на високопродуктивних доїльних установках.

В останні роки в Україні створено декілька ферм 3 ресурсоощадними технологіями виробництва молока в основу яких покладено легкозбірні корівники 3 новими об'ємно-планувальними і технологічними рішеннями шириною 32,5 та 36 м.

Різна ширина цих приміщень обумовлена, в першу чергу, необхідністю використання різних систем доїння. Так, в приміщенні шириною 32,5 м передбачено утримання 340 голів корів 3 доїнням їх на спеціалізованому доїльному майданчику установки типу «Паралель», а в приміщенні шириною 36 м для доїння корів використовуються роботизовані системи доїння фірми DeLaval, які розміщенні по центру приміщення. Тому, для комфортного пересування корів до роботизованих систем доїння і збільшена ширина приміщення (Lutsenko and Sameha, 2007; Grainger et al., 2008; Schöne et al., 2009; Reyd, 2010).

За об'ємно-планувальними і технологічними рішеннями ці типи приміщень практично не відрізняються одне від одного. Вони зорієнтовані на безприв'язно-боксову технологію утримання тварин, облаштовані боковими шторами і світлоаераційним гребенем, годівля корів здійснюється з кормового столу, а напування - 3 групових напувалок. Суттєва різниця між приміщеннями обумовлена їх шириною та використанням різних систем доїння. 
Враховуючи те, що такі типи приміщень в Україні побудовані вперше надзвичайно важливо було провести оцінку якості їх функціонування в екстремальні періоди року, дослідити комфортність умов утримання високопродуктивних корів при використанні різних систем доїння 3 тим щоб рекомендувати їх для широкого впровадження в Україні.

Мета досліджень - дослідити якість функціонування нових типів легкозбірних корівників шириною 32,5 і 36 м, висотою 10,5 м в умовах України у порівнянні $з$ традиційними приміщеннями шириною 24 м.

\section{Матеріал та методи досліджень}

Дослідження виконано на молочній фермі ТДВ «Терезине» Білоцерківського району Київської області. В даному господарстві впроваджено нові ресурсо- ощадні технології виробництва молока з використанням різних систем доїння: доїльної установки типу «Паралель» та роботизованих систем доїння фірми DeLaval.

Дослідження проведені з використанням хронометражних спостережень, зоотехнічних та хімічних методів.

\section{Результати та їх обговорення}

Дослідження проводились 3 використанням трьох типів тваринницьких приміщень: традиційного корівника шириною 24м, що в даний час використовуються на фермах України і два типи легкозбірних приміщень шириною 32,5 і 36 м. основні параметри цих приміщень викладені в табл. 1.

Таблиця 1

Основні параметри корівників

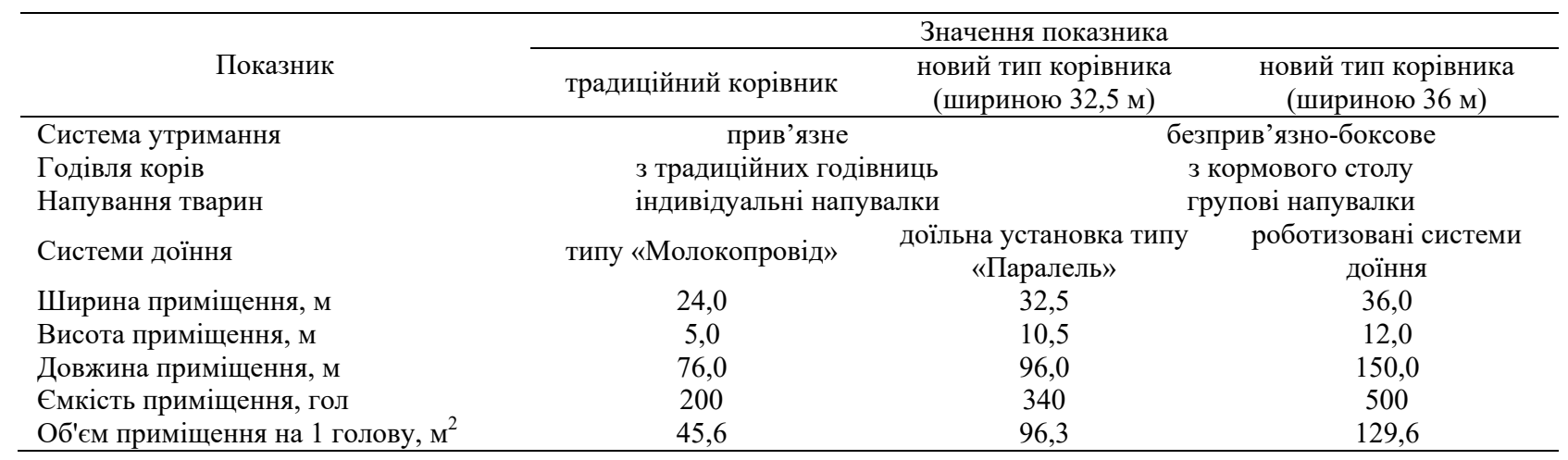

Результати, що викладені в таблиці 1 свідчать про те, що основні параметри нових типів приміщень: ширина і висота суттєво відрізняються від традиційних. Збільшення цих параметрів значно збільшило їх ємкість. При цьому об'єм приміщення на 1 голову в корівнику шириною 32,5 у порівнянні 3 проектним корівником шириною 24 м збільшився у 2,1 рази, а шириною 36 м - у 2,8 рази. Таке збільшення об'єму приміщень на 1 голову повинно було значно покращити умови утримання високопродуктивних корів.

Дослідження основних параметрів мікроклімату в цих типах приміщень показали, що збільшення об'єму приміщення на 1 голову значно покращують його параметри (табл. 2).

\section{Таблиця 2}

Показники мікроклімату в різних типах приміщень в зимовий період

\begin{tabular}{|c|c|c|c|c|}
\hline \multirow[b]{2}{*}{ Показник } & \multicolumn{4}{|c|}{ Значення показника } \\
\hline & $\begin{array}{c}\text { нормативні } \\
\text { параметри за } \\
\text { ВНТП-АПК }\end{array}$ & $\begin{array}{c}\text { традиційний } \\
\text { корівник }\end{array}$ & $\begin{array}{c}\text { новий тип } \\
\text { корівника } \\
\text { (шириною } 32,5 \text { м) }\end{array}$ & $\begin{array}{c}\text { новий тип корівника } \\
\text { (шириною } \\
36 \mathrm{M})\end{array}$ \\
\hline Швидкість руху повітря, м/с & $0,3-0,4$ & $0,16 \ldots 0,27 \pm 0,05$ & $0,5 \pm 0,09 * * *$ & $0,52 \pm 0,02 * * *$ \\
\hline Освітлення в зоні годівлі, лк & 52,0 & $31,0 \pm 2,7$ & $49,0 \pm 3,2 * *$ & $70,0 \pm 15,0 * * *$ \\
\hline $\begin{array}{l}\text { Загазованість повітря: } \\
\text { аміак, мг/м }\end{array}$ & 20,0 & $10,5 \pm 0,5$ & $1,3 \pm 0,25 * * *$ & $3,0 \pm 15,0 * * *$ \\
\hline вуглекислий газ, \% & 0,25 & $0,75 \pm 0,05$ & $0,05 * * *$ & $0,3 * * *$ \\
\hline $\begin{array}{l}\text { Бактеріальне забруднення } \\
\text { повітря, тис/м }{ }^{3}\end{array}$ & до 70,0 & $493,6 \pm 0,57$ & $26,4 \pm 2,5 * * *$ & $2,8 \pm 1,3 * * *$ \\
\hline
\end{tabular}

Примітка: **-P>0,99; ***-P >0,999

Встановлено, що нові об'ємно-планувальні і технологічні рішення корівників забезпечують комфортні умови утримання високопродуктивних корів. Наявність в конструкції цих приміщень бокових штор i світлоаераційного гребеня збільшують швидкість руху повітря більше ніж у - 3 рази (до 0,5...0,52 м/с проти 0,16 м/с у традиційних корівниках), виключаючи при цьому протяги, що позитивно впливає на загазованість приміщень та бактеріальне забруднення повітря. Наявність аміаку в нових легкозбірних корів- 
никах у 8... 9 рази менше у порівнянні з традиційним корівником і у $15,3 \ldots 6,6$ разів менше у порівнянні 3 вимогами норм технологічного проектування ВНТПАПК-0,1-0,5 (Р > 0,999).

Бактеріальне забруднення повітря у корівнику шириною 32,5 м у 2,6 рази менше у порівнянні з нормативами та у 18,7 разів менше у порівнянні з традиційним корівником. Збільшення об'єму приміщення шириною до 129,6 м ${ }^{3}$ на 1 голову знижує бактеріальне забруднення повітря у зимовий період до мінімального значення 2,8 тис/м ${ }^{3}(\mathrm{P}>0,999)$.

Нові елементи в конструкції легкозбірних приміщень забезпечують ресурсозбереження і при організації їх освітлення.

Згідно існуючих в Україні нормативів освітлення в зоні годівлі тварин повинно бути на рівні 52 лк. В традиційних приміщеннях такий рівень досягається лише шляхом встановлення додаткових джерел енер- гіï, які і забезпечують підвищення рівня освітлення 3 31 лк до 52 лк. В нових типах приміщень необхідний рівень освітлення забезпечується природним шляхом, що приводить до значної економії енергоресурсів.

Відомо, що для нормального функціонування високопродуктивних корів важливе значення має не лише мікроклімат приміщення, а і організація повноцінного відпочинку. Встановлено, що кожна додаткова година відпочинку тварини забезпечує збільшення молочної продуктивності на 1 кг. Тому надзвичайно важливо, щоб об'ємно-планувальні і технологічні рішення приміщень, в яких вона утримується, забезпечували комфортні умови відпочинку. В зв'язку 3 цим поряд 3 дослідженнями мікроклімату в різних типах приміщень,ми, шляхом хронометражних спостережень, досліджували і поведінку високопродуктивних корів (табл. 3).

\section{Таблиця 3}

Поведінка корів у різних типах приміщень

\begin{tabular}{|c|c|c|c|c|c|c|}
\hline \multirow{3}{*}{ Показник } & \multicolumn{6}{|c|}{ Значення показника } \\
\hline & \multicolumn{6}{|c|}{ Тип корівника } \\
\hline & \multicolumn{2}{|c|}{$\begin{array}{c}\text { традиційний } \\
\text { шириною } 24 \text { м }\end{array}$} & \multicolumn{2}{|c|}{$\begin{array}{c}\text { легкозбірний, } \\
\text { шириною 32,5м }\end{array}$} & \multicolumn{2}{|c|}{$\begin{array}{l}\text { легкозбірний, } \\
\text { шириною } 36 \text { м }\end{array}$} \\
\hline Спосіб утримання & \multicolumn{2}{|c|}{ прив'язний } & \multicolumn{2}{|c|}{ безприв'язний } & \multicolumn{2}{|c|}{ безприв'язний } \\
\hline Тривалість акту поведінки & XB. & $\%$ & XB. & $\%$ & XB. & $\%$ \\
\hline Лежать бездіяльно, & 667,2 & 46,34 & $750 * *$ & 52,1 & $801 * * *$ & 55,6 \\
\hline 3 них жують жуйку & 149,6 & 22,43 & 174,7 & 23,3 & 182,0 & 22,72 \\
\hline Стоять бездіяльно, & 431,6 & 29,98 & 262,2 & 18,2 & 215,0 & 14,9 \\
\hline 3 них жують жуйку & 66,2 & 13,29 & 17,2 & 14,2 & 15,1 & 7,02 \\
\hline Пересуваються & - & - & 123,0 & 8,6 & 142,0 & 9,9 \\
\hline Споживають корм & 320,2 & 22,23 & $252,0 * *$ & 17,4 & $246,0 * *$ & 17,1 \\
\hline Споживають воду & 13,8 & 0,95 & 19,8 & 1,4 & 19,0 & 1,3 \\
\hline Доїння & 7,2 & 0,5 & 33,0 & 2,3 & 17,0 & 1,2 \\
\hline
\end{tabular}

Примітка: **-P>0,99

Етологічні дослідження показали, що об'ємнопланувальні та технологічні рішення нових типів корівників і технологія утримання високопродуктивних корів забезпечують більш комфортні умови їх утримання. Так, у нових типах корівників тварини відпочивають у бездіяльному стані 750-801 хв, що на $12,4 \%$ та 20\% більше у порівнянні $з$ традиційним корівником $(667,2)$. Годівля корів у легкозбірних корівниках з кормового столу забезпечує швидке насищення тварин кормом. При цьому затрати часу на споживання корму в нових типах корівників достовірно менше і складає всього 252,0-246 хв на добу проти 320,2 хв $(\mathrm{P}>0,99)$ у традиційних приміщеннях де годівля здійснюється 3 традиційних годівниць.

Позитивним $є$ і те, що при використання легкозбірних корівників у тварин появляється надзвичайно важливий елемент поведінки - вони пересуваються впродовж доби 123-142 хв, що складає 8,6 ... 9,9\% часу доби. Усе це забезпечує моціон тварин, який позитивно впливає на їх фізіологічний стан.

\section{Висновки}

Таким чином проведені дослідження з оцінки різних типів тваринницьких приміщень показали високу ефективність легкозбірних корівників і в екстремальні періоди року. Об'ємно-планувальні і технологічні рішення цих типів приміщень забезпечують комфортні умови утримання високопродуктивних корів, ресурсозбереження за рахунок природнього освітлення та дозволяють ефективно використовувати сучасні високопродуктивні доїльні установки.

\section{References}

Lutsenko, M.M., Ivanyshyn, V.V., \& Smoliar, V.I. (2006) Perspektyvni tekhnolohii vyrobnytstva moloka [Promisingmilkproductiontechnologie]: monohrafiia. K.: Vydavnychyi tsentr «Akademiia» (in Ukrainian).

Lopez, H., Satter, L.D., \& Wiltbank, M.C. (2004). Relationship between level of milk production and estrous behavior of lactating dairy cows. Animal Reproduction Science. 81(3-4), 209-223. doi: 10.1016/j.anireprosci.2003.10.009.

Guetouache, M., Guessas, B., \& Medjekal, S. (2014). Composition and Nutritional value of raw milk. Issues in Biological Sciences and Pharmaceutical Research. 2(10), 115-122. doi: 10.15739/ibspr.005.

Mazurenko, O.V. (2011). Tendentsii rozvytku tvarynnytstva $\mathrm{v}$ Ukraini. [Trends in livestock 
development in Ukraine]. Ekonomika APK. 9, 16-21 (in Ukrainian).

Norman, H.D., Miller, R.H., Wright, J.R., Hutchison, J.L., \& Olson, K.M. (2012). Factors associated with frequency of abortions recorded through Dairy Herd Improvement test plans. Journal of Dairy Science. 95, 4074-4084. doi: 10.3168/jds.2011-4998.

Bozhydarnyk, T.V., \& Krysanov, D.F. (2011). Napriamky rekonstruktsii molochnoho sektoru ekonomiky [Areas of reconstruction of the dairy sector of the economy]. Visn. ahrar. Nauky. 8, 66-69 (in Ukrainian).

Bilchenko, H. (2011). Novyi korivnyk vlasnymy sylamy. [The new barn on their own]. Ahroekspert. 3(32), 72 75 (in Ukrainian).

LeBlanc, S.J. (2013). Short communication: Field evaluation of a pregnancy confirmation test using milk samples in dairy cows. Journal of Dairy Science. 96, 2345-2348. doi: 10.3168/jds.2012-6414.

Rushen, J., de Passillé, A.M.B., \& Munksgaard, L. (1999). Fear of People by Cows and Effects on Milk Yield, Behavior, and Heart Rate at Milking. Journal of Dairy Science. 82(4), 720-727. doi: 10.3168/jds.S0022-0302(99)75289-6.

Ghassemi Nejad, J., Kim, B.W., \& Lee, B.H. (2017). Coat and hair color: hair cortisol and serotonin levels in lactating Holstein cows under heat stress conditions. Animal Science Journal. 88(1), 190-194. doi: 10.1111/asj.12662.

Lutsenko, M.M., \& Sameha, D.V. (2007). Doslidzhennia vplyvu novykh obiemno-planuvalnykh rishen lehkozbirnykh prymishchen na umovy utrymannia koriv u litnii period [Investigation of the influence of new volumetric-planning decisions of easy-assembled premises on the conditions of keeping cows in the summer]. Naukovyi visnyk Lvivskoho natsionalnoho universytetu veterynarnoi medytsyny ta biotekhnolohii im.S.Z. Hzhytskoho. 9, 3(34), 220-227 (in Ukrainian).

Grainger, C., Clarke, T., Beauchemin, K.A., McGinnS, M., \& Eckard, R.J. (2008). Supplementation with whole cottonseed reduces methane emissions and can profitably increase milk production of dairy cows offered a forage and cereal grain diet. Australian Journal of Experimental Agriculture. 48(2), 73-76. doi: 10.1071/EA07224

Schöne, F., Leiterer, M., Lebzien, P., Bemman, D., Spolders, M. \& Flachowsky, G. (2009). Iodine concentration of milk in a dose-response study with dairy cows andimplications for consumer iodine intake. Journal of Trace Elements in Medicine and Biology. 23, 84-92. doi: 10.1016/j.jtemb.2009.02.004.

Reyd, D. (2010). Effektivnaya rabota doilnogo zala. [Efficient operation of the milking parlor]. Molochnoe skotovodstvo. 2, 39-40 (in Ukrainian).

Smoliar, V. (2010) Kompleks tekhnichnykh zasobiv dlia realizatsii resursooshchadnoi tekhnolohii vyrobnytstva moloka. [Complex of technical means for realization of resource-saving technology of milk production]. Tekhnika i tekhnolohii APK. 4, 8-12 (in Ukrainian).

Kelly, M.L., Berry, J.R., Dwyer, D.A., Griinari, J.M., Chouinard, P.Y., Van Amburgh, M.E., \& Bauman, D.E. (1998). Dietary fatty acid sources affect conjugated linoleic acid concentrations in milk from lactating dairy cows. The Journal of Nutrition. 128(5), 881885. doi: 10.1093/jn/128.5.881.

Kudlai, I. (2010). Tekhnolohichne vdoskonalennia molochnykh ferm [Technological perfection of dairy farms]. Tvarynnytstvo Ukrainy. 2, 5-6 (in Ukrainian). 